Alicante Journal of English Studies 26 (2013): 259-270

\title{
The Spectral Evidence of Photography in Rachel Seiffert's The Dark Room: An Album of Fractured Lives
}

\author{
María Jesús Martínez Alfaro \\ University of Zaragoza \\ jmartine@unizar.es
}

\begin{abstract}
This article focuses on Rachel Seiffert's The Dark Room (2001), which I place in the context of what Froma I. Zeitlin (2006) regards as an emerging trend in Holocaust literature: fictional stories that move away from the victims and focus instead on the victimisers, as well as on the impact and legacy of the Nazi period on average Germans. The Dark Room consists of three independent but related stories, entitled after each German protagonist, and taking place in Germany at different moments of the 20th century. It is my aim to analyse the themes that connect these three stories - loss, guilt, shame, secrets and deception, traumatic awakenings and the fall from innocence, the crisis of identity, etc. - and to relate them to the motif already suggested by the work's title: photography. Pictures recur insistently throughout the book's pages and, like the past, they constitute a spectral presence in Seiffert's novella triptych, where photographs emerge as a vehicle for exploring the problems posed by photographic evidence. Thus, I argue, the thread that ultimately weaves the stories together has to do with each protagonist's negative epiphany, that is to say, his/her painful discovery that, in spite of all that a picture can be said to capture or show, the truth turns out to be disturbingly absent, lying in an unreachable elsewhere, always beyond the frame.
\end{abstract}

While narratives of loss, oppression and trauma are by no means new, there is no denying that the particular dedication of the humanities to these issues has reached a new quality from the 1990s onwards. As the concept of trauma has gradually travelled 
from medical and scientific fields to the discourse of the humanities, trauma can be said to have emerged as a major concern in the area of literary studies.

Within the field of trauma studies and trauma literature, the Holocaust figures prominent. Holocaust testimony emerged as a distinct genre in the 1980s and 1990s, and its conventions were defined by key trauma theorists such as Lawrence Langer, Dori Laub and Shoshana Felman. The outpour of diaries, memoirs and novels by survivors have also shown their commitment to a duty: that of bearing witness. Survivors' narratives made for a new genre and they also created an "other": fictionalised accounts of the Holocaust, which have sometimes been questioned, and other times welcomed as fulfilling the function of imaginary witnesses.

Bearing witness is often associated with the victims and their descendants. I would like to emphasise the point here that bearing witness requires that we consider not only those to whom the Holocaust happened, but also those who made it happen, that is, the perpetrators. It is hard to try and put oneself in the place of a victim, but it is also an ethical exercise to open one's eyes to the commonality of the perpetrators. Todorov explains that, having suffered the persecutions and humiliations they did, it was important for the victims to insist that they were human beings. Today, however,

when everyone recognizes the humanity of the victims, it is not enough to be able to say, "We are human like them." We must also grapple with the more problematic comparison, between ourselves and the executioners, and be prepared to say, "They are human beings like us." Those who took an active part in the perpetration of evil were ordinary people, and so are we: they are like us, we are like them. (1997: 135)

Some fiction writers dealing with the Holocaust and its aftermath have for different reasons chosen to focus not on the victims but on the perpetrators. This is, for instance, the case with Martin Amis and Time's Arrow. In an interview, the author remarks: "People say, legitimately in a way, what am I as an Aryan doing with this subject? But I'm writing about the perpetrators and they are my brothers, if you like. I feel a kind of responsibility in my Aryanness for what happened. This is my racial link with these events, not with the sufferers but with the perpetrators" (Wachtel, 1996: 47).

In an interview on the publication of The Dark Room (2001), Rachel Seiffert complains that "not nearly enough has been done to investigate the perpetrators" experiences" ("Author Interview", 2009). ${ }^{1}$ The reader who ventures him/herself into the forest of Holocaust literature cannot but agree with Seiffert's remark. The number of books dealing with perpetrators' or ordinary Germans' experiences during and after the war is not comparable with the number of books about the victims and their descendants. It must be admitted, though, that such a state of affairs has begun to change. More scientific and medical research has been done on this field in the last decades, ${ }^{2}$ and also more fictional literature has been published dealing with the Holocaust and its aftermath in connection not with the victims, but with their "others." Thus, in an article published in 2006, Froma I. Zeitlin focuses on what she sees as an emerging trend in Holocaust literature which she refers to as "imaginary tales in the land of the perpetrators": fictional stories that move away from the victims and deal 
instead with the victimisers, as well as with the impact and legacy of the Nazi period on average Germans.

Rachel Seiffert's The Dark Room is one of the works analysed in Zeitlin's article as illustrative of "a critical shift of point of view that addresses the Nazi era from within its own territory and frames of reference [...] without ever falling into the equally treacherous alternatives of demonization or exculpation" (2006: 216). ${ }^{3}$ The Dark Room - Seiffert's first published work - can be described as a novella triptych consisting of three independent though thematically connected stories whose titles coincide with the name of each protagonist: Helmut, Lore, and Micha. None of the three main characters commit atrocities, but their lives are connected with and variously affected by Nazism. The work juxtaposes three slices of life that portray three generations of Germans whose stories take place during World War II ("Helmut"), immediately after it ("Lore"), and in the late 1990s ("Micha"). By providing different perspectives and focusing on different historical periods, Seiffert's work invites readers to consider the full spectrum of those affected by the Holocaust as well as the way in which the repercussions of the Third Reich are still felt.

Pictures are a most outstanding motif in the three stories, and the title of the book is already evocative of photography. The title phrase also suggests a place where things are hidden, thus figuratively pointing to one of the work's main themes: the dilemmas that come with the discovery of knowledge that is difficult to admit, even to oneself; the existence of buried memories and secrets that are too painful to disclose. In the light of the narratives that make up the book, the darkness of the dark room and its link with photography ultimately brings to mind Ulrich Baer's reference to photographs — and photographs of trauma in particular - as a kind of "spectral evidence", revealing "the striking gap between what we can see and what we can know" (2002: 2).

As if to strengthen the connection between photography and narrative, the style in which the work is written could be described as "photographic" (Tollance, 2005). It is a laconic style, the text is fragmented into short paragraphs separated from one another by a blank space, and sentences are written in the present tense, as if a hypothetical gaze were describing the scene just as one describes pictures by means of captions. This style and the recurrent presence of photographs in the work ${ }^{4}$ contribute to the reader seeing it as a photo album of sorts, which consists of three smaller albums: those of Helmut, Lore, and Micha. As has been pointed out, the title of each story coincides with the name of its protagonist, but it could equally be a word written under a picture to indicate who the photographed person is. Just as each picture in an album is part of the story that emerges from the album and tells itself a story, so each of the book's three sections is part of a larger whole and a whole in itself. As happens when seeing an album, the further one reads into the book, the closer one gets to the present time.

The first story, "Helmut", takes place from 1921 to 1945. Main character Helmut is fervently patriotic and unquestionably supports the Nazi cause. The tragedy of his life is that he cannot serve in the army due to the partial paralysis of his arm, a physical disability he was born with. This being so, young Helmut starts working for his father's former employer, the photographer Gladigau, who soon becomes aware of the boy's 
talent for photography and even imagines him "a suitable heir for his modest business empire" .

Helmut frantically documents wartime Berlin but his pictures, like all pictures, are far from being codeless analogues of reality. Despite the feeling that a picture captures "the real thing", truth is always partial in photography as every picture can be said to show and hide at the same time. Throughout the three stories that make up The Dark Room, Seiffert highlights this dual nature of photography, which Marianne Hirsch explains in the following terms:

In spite of their evidential force and their material connection to an event that was there before the lens, photographs can be extremely frustrating, as fleeting in their certainty as footprints in the snow. They affirm the past's existence, its "having-been-there"; yet, in their flat two-dimensionality, in the frustrating limitation of their frames, they also signal its insurmountable distance and unreality. What ultimately can be read as we read an image? Does it not [...] conceal as much as it reveals? (2001: 14)

That photographs can be frustrating in their failure to capture reality is something that Helmut will eventually discover but, before that happens, he makes of photography the cornerstone of his identity. The malfunctioning of his arm has excluded him from a militarist society in which he would have liked to take an active part. It has also turned him away from the kind of son that would have made his father proud and happy. Thus, photography becomes a way of participating by proxy in things he is barred from, and a way of showing his family there is something he is good at. Photography seems to give him a sense of identity and belonging. It is also a kind of hiding place, like the dark room in Gladigau's shop where he likes spending his time and where he feels safe and happy. As a photographer, he looks instead of been looked at and he hides behind the camera. In important respects, one could even say that Helmut becomes himself a camera, recording but never thinking, scrutinising everything but showing no moral awareness of what he sees.

In the story's climactic moment, Helmut comes across a rounding up of gypsies in the backstreets of Berlin. He photographs the scene trying to capture all the confusion and violence of the moment, frightened but also exhilarated by it. He takes pictures as quickly as the camera allows till one gypsy notices his presence and stares at him. Helmut runs away, unable to meet the eyes of the shouting gypsy. The camera hides Helmut from the gaze of the world, but he cannot cope with it when the world, as it were, starts looking back at him through the lens. He rushes to the dark room and develops his film only to discover that the photographs do not show what he observed:

The bright skirts of the gypsy women are just drab rags in his photos [...]. The dark SS uniforms blend into the soot-black walls of the buildings making them almost invisible [...]. He blows up the image, but the grain evens out the lines on the face of the officer who was screaming orders by the jeep, and he barely looks like he is shouting. [...] Helmut searches and searches, but the shot of the gypsy looking into his lens, pointing and shouting $[\ldots]$ is not amongst the photos. (TDR 40) 
Both the negatives and the pictures end up in the trash can.

Helmut's complaints are all related to technique and aesthetics, which highlights even more his lack of moral vision and leads the reader to reflect on photography in connection with the photographer's moral gaze. Professional photographers who take pictures of extreme realities, like war, natural catastrophes, etc., have sometimes referred to the camera as a kind of protective object that shields the person looking through the lens from the horror of what is being photographed. George Rodger, one of the photographers that participated in recording the camp liberations after the war, commented about his documentation of Belsen in similar terms: "I discovered that I could look at the horror of Belsen - the 4000 dead and starving lying around - and think only of a nice photographic composition. I knew that something had happened to me and it had to stop" (qtd. in Osman, 1987: 259). This shock at the lack of an emotional response and Rodger's perception of it as a sign that something was going wrong is precisely what Helmut lacks. To Susan Sontag, "[w] hat determines the possibility of being morally affected by photographs is the existence of a relevant political consciousness" (1977: 19). And Helmut has none. He will never question or even think about what is happening around him - the raided Jewish shops, the deportations, the exodus of refugees, etc. The reader sees him keeping his allegiances to an ideology that marginalises others, but that also excludes him. In its obsession with purity, Nazism aimed at cleansing the collective body from what was regarded as human vermin and parasites. These included the Jews, the gypsies, the homosexuals and the disabled, like Helmut. And yet, he defends the Reich even when it is obviously collapsing and Berlin is bombed to rubble.

As a child, Helmut becomes aware of his being different from the rest when he starts going to school. The sports teacher pulls him out of the line and groups him with "the fat boys and the weak boys with bad teeth" (TDR 8). Only then does he realise that there is something wrong with him. The story ends with Helmut being at last given his chance, which restores his sense of belonging. As he is enlisted, he gets a tatty greatcoat, an armband and a shovel, like others who become now a group which Helmut proudly feels part of. Significantly, this group is made up of "the fat boys and the weak boys with bad teeth, the old men and amputees" (TDR 62). The narrator describes them as happy against the background of a destroyed city. This heterodiegetic voice anticipates what is soon to come:

In a matter of days, a suicide will speed the Soviet invasion; the small mound of broken building will mark the line between what is British, what is French; and Helmut will not recognise his childhood home in the Berlin which is to come. But in this photo, Helmut is doing something he never did in any of the many pictures lovingly printed by Gladigau in the course of his childhood. Helmut is standing high on his rubble mountain, over which the Soviet tanks roll with ease, and he is smiling. (TDR 63)

In the story's final paragraph, the narrator shifts to the future tense and anticipates events the reader is already aware of, thus creating dramatic irony at the expense of Helmut's blindness. 
Taken together, the three stories that make up The Dark Room reflect a progress in moral awareness, an evolution from Hitlerian delusion and postwar denial to a readiness for truth and responsibility (Sacks, 2001). Thus, while Helmut shows a complete lack of understanding and moral awareness, the protagonist of the second story, Lore, illustrates the pain that comes with the fall from innocence and the confusion felt by someone who begins to understand, but does not quite apprehend, the dimension of what has happened during the war.

This second story picks up where "Helmut" ends, that is, at the end of the war. Lore is a young adolescent whose $S S$ father has disappeared and whose mother is about to be imprisoned by the victorious Allied forces. Before that happens, she asks Lore, her eldest daughter, to take her four siblings to Hamburg, where their grandmother lives. The story focuses on the children's precarious journey through a defeated Germany and Lore's efforts to reach their destination while she starts to become dimly aware of the sins of her country, which are also the sins of her parents.

Like the other two stories in The Dark Room, "Lore" combines family portraits and documentary photographs in a way that shows how the individual and family are interconnected with history (Zeitlin, 2006: 225). At the beginning of the narrative, Lore's mother goes through the family album, removing incriminating pictures. She wants to protect her Nazi husband from accusation and the rest of the family from association with him, so photographs are burned and other objects like insignia and badges are thrown into the river. As Hirsch and Spitzer (2006: 239) point out, photographs are given evidentiary power here. However, the evidentiary authority of the photograph is utterly undermined at the end of the story, when Lore finds out that Thomas, the mysterious young man who helps the children to reach Hamburg, managed to do so by repeatedly showing to the Allied soldiers the papers and the photograph of another man, a Jew dead in a camp, whom he resembled. If the pictures in the family album may bring about danger and even death - because they reveal the truth about the family's allegiances - it is also thanks to a picture which helps to fake someone's identity that the main characters make their way into safety and freedom.

This ambiguity surrounding pictures and their evidentiary power turns them into a symbol of a reality in which crucial distinctions have suddenly blurred for the young protagonist. The upheaval brought about by the war can only be met with bewilderment by Lore. Her parents have ceased to be model figures and are now regarded as criminals. The family's commitment to Nazi ideology had to be exhibited and was a source of pride; now they have to be silent, and even lie about it, because what was right has turned wrong and shameful. Lying was bad, but now it is the only means to survive. Thomas was good to them, but he was also a fraudster, someone whose true identity remains unknown and who eventually disappears without leaving a trace.

The alienating power of reality is best illustrated by the photographs used as pedagogic displays which Lore comes across several times in the course of the narrative. These photographs are part of the Allied poster campaigns instructing German civilians about the suffering endured in the concentration camps. The first time she sees these pictures, Lore is in the market square of a village, trying to get some food 
for her and her siblings. The photographs have been glued on a tree and the villagers crowd around them, trying to decipher them as the glue under the photos

is still wet, the paper is wrinkled, and the images confusing [...]. The pictures are of skeletons. [...] Hundreds of skeletons; hips and arms and skulls in tangles. Some lying in an open railway carriage, others in a shallow hollow in the ground. Lore holds her breath, looks away, sees the next picture; hair and skin and breasts. She takes a step back, trapped by the wall of the crowd. (TDR 103)

At a time in which photographs like these have been shown and seen so many times that some even fear we have become desensitised to the horrors they portray, Seiffert recreates the moment in which such pictures were seen for the very first time. If Helmut discards his photographs because they fail to capture the reality he observed, Lore cannot assimilate the import of the pictures she sees simply because they do not reproduce any known or even plausible reality. She overhears two boys talking about the pictures as evidence of Allied propaganda, convinced as they are that the people in them are all actors. And this is also what Lore believes until, once in Hamburg, two women reading a newspaper which contains other similar pictures bluntly tell her that this is what the Nazis did, which makes Lore think of what her own father could have done. Disbelief is then replaced by something different which never takes a definite shape as Lore's attempts to understand always clash with the silence of those close to her.

Though Lore manages to reach Hamburg, she does not bring all her siblings with her. One of the twins, Jochen, was shot by the Russians in a wood and died there, but none asks her about her brother when they arrive at their grandmother's home. When her mother writes to her from a camp, there is no question about Jochen, either, just as there is no information about her present circumstances. Later on, Lore's mother sends a photo of herself to her children, a photo which could have been taken anywhere and which thus hides rather than reveals what Lore would like to know. She craves for a story that elucidates the picture, be it the fake photograph of Thomas, the photographs of dead and emaciated camp inmates, or the photograph of her mother. But as nobody seems willing to tell, Lore ends by internalising the silence that surrounds her: her wish to know gives way to a wish to forget. This silence which characters comply with in "Lore" epitomises what psychologist and journalist Peter Sichrovsky refers to as the movement from "collective barbarism to collective amnesia" in post-war Germany (1998: 12). And so, the second story in The Dark Room ends with its protagonist looking forward to "when there will be no more ruins, only new houses, and she won't remember any more how it was before" (TDR 217).

The silence about their ancestors' past is something that affects the descendants of both victims and perpetrators. This silence and pervading secrecy may take the form of transgenerational haunting, since, as Nicolas Abraham argues, "what haunts are not the dead, but the gaps left within us by the secrets of others" (1987: 287). ${ }^{6}$ The protagonist of the last story in The Dark Room illustrates the effects that this transgenerational haunting of an ancestor's silenced past may have on succeeding generations. 
Set in the late 1990s, "Micha" begins by providing information on the protagonist's life and routines. Michael Lehner (Micha) is a secondary school teacher of English in an unnamed German town where he lives with his girlfriend Mina, a physiotherapist of Turkish descent. During one of Micha's visits to his grandmother Kaethe, the old woman innocently reveals to him that his Opa Askan was Waffen SS. Micha is surprised to hear that his grandfather, dead for twenty five years, was a member of the $S S$ elite military force. Suspecting that there is a most important chapter of the past which his family has silenced, Micha gets determined to find out the truth about the extent of his grandfather's implication in the crimes of Nazism.

According to Gabriele Rosenthal, "the third generation, in contrast to their parents, are beginning much more to act out the symptoms that correspond to the family's Nazi past and by doing so are beginning to expose and confront this past" (1998: 247). Thus, in Seiffert's story it is a representative of the third generation who illustrates the attempt to break the wall of silence erected to keep the past at a distance. In contrast with Micha, his mother and his uncle - representatives of the second generation, the same as Lore in the previous section- prefer to leave things as they are. They prefer, that is, to hold on to the family myth, best represented in the story by the photo album that Micha's grandmother treasures and proudly shows to her grandson when he visits her. Kaethe's photo album contains the family history while simultaneously editing out part of that history, the incriminating part, shameful and upsetting. As the protagonist's elder sister tells him, those pictures "don't show anything, they are always happy" (TDR 372). To Susan Sontag, the pictures in a photo album give us "an imaginary possession of a past that is unreal" (1977: 9). The album helps not only to remember but also to forget. Thus, Micha tries to discover the truth elsewhere: in war crimes databases and in the books and video archives on the Holocaust kept at the university library. Far from giving in when his search brings no result, the protagonist of this third story becomes increasingly obsessed with finding out.

One day, Micha steals a photograph of his grandfather from his grandmother's album, a picture of Askan Boell when he was young, taken during the couple's honeymoon. When he looks at the picture he sees just Opa, but he is unable to reconcile the man in the photo with the man in his head: Nazi Opa (TDR 269). The honeymoon photograph of Micha's grandfather becomes a sort of haunting spectre which will not go away. ${ }^{7}$ This photo will be travelling in Micha's pocket from the beginning to the end of the story, demanding a narrative that rescues the dumb image from silence. It is in search of this narrative that Micha decides to go to Belarus, where Askan spent the last years of the war. What he wants to know is the answer to a question that he can barely say inside, but that stays on his mind just as the picture stays in his pocket. He wants someone to show the picture to, as he asks: "This is my Opa. Do you remember him killing the Jews?" (TDR 310, emphasis in the original).

On the pretext that he is doing research, Micha interviews a man who collaborated with the Germans, Jozef Kolesnik, in the same village where his grandmother situated Askan at the end of the war. Kolesnik's testimony is full of pauses, gaps and silences, but he does not try to make excuses or to provide reasons that may soften the atrocities 
committed. As he bluntly admits: "I chose to kill" (TDR 345). There is no weakness in him and no tears. "How can I apologise?", he says, "[w] ho is there to forgive me?" (TDR 355). As if drawn by the fear of merger with a man that is the closest he can get to his grandfather, Micha takes a photograph of Kolesnik and his wife Elena, but when the latter offers to take a picture of him and her husband, he refuses and hurts them both.

When he at last shows Kolesnik his grandfather's honeymoon photograph, and the old man recognises him, Micha poses the question he has been eluding for so long: "Did you see my Opa do anything?" (TDR 362, emphasis in the original). Kolesnik's answer is not utterly conclusive. On the one hand, he cannot say that he saw Askan shooting, because he never did; on the other hand, he has clear memories of the few who refused to kill, so if Micha's grandfather had been among them, he would remember. Micha cannot be completely sure but, in his heart of hearts, he knows that his grandfather was among the murderers.

Seiffert's "Micha" highlights the fact that buried secrets eventually return to become haunting spectres difficult to exorcise. But the story also raises the disturbing question of whether by not refusing memory, as Micha does, one can truly purge oneself of its wounds. The protagonist himself reflects that something he has discovered after all this time is that there is no end to it, no end to the haunting, no end to the past (TDR 380).

To Petra Rau, Micha's "transgenerational response to traumatic exposure is less a working through than an irresolvable 'working towards' it" (2006: 296). To Pascale Tollance, Micha's quest is "a journey out of silence and towards silence" (2005: 297). In order to go beyond what these critics see as the (bleak) outcome not only of this story but of the whole made up by the three sections into which the work is divided, it is worth focusing on the very last scene, the last picture in the album. This last still, so to put it, brings together several generations. It is telling that while Micha delves into the past to find out about his grandfather, he becomes himself a father, the father of a girl they call Dilan after Mina's (Turkish) grandmother. When Mina suggests that name, Micha is relieved that she has thought of her grandmother and not his. For some time, he has been unable to visit his Oma Kaethe again, unable, that is, to reconcile the present and the past. And yet, the story ends on a beautiful spring day, with Micha taking his daughter - already a toddler - to visit Kaethe for the first time. The young girl and her laughter, the time of the year, Micha's resuming his visits to his grandmother, they all suggest renewal and at least a measure of reconciliation. At the end of "Micha", Oma Kaethe and Dilan, the past and the future, wave at one another and Micha makes their meeting possible, in the present.

The reader may wonder whether, at some point during that visit, Micha will at last restore Askan's honeymoon picture to his grandmother's album, where it left a conspicuous gap suggestive of other invisible gaps and fractures. One could say, though, that the gap has become one with the picture, as the story of the man it portrays cannot be wholly retrieved. Significantly, the author points out that, for her, the photo theme in The Dark Room is about "the desire to clarify and document, and the impossibility of this process" ("Author Interview", 2009, emphasis in the original). 
Gaps and pictures go together in the three stories. In fact, the thread that ultimately weaves the book's three sections together has to do with each protagonist's negative epiphany, that is to say, his/her painful discovery that, in spite of all that a picture can be said to capture or show, the truth turns out to be disturbingly absent, lying in an unreachable elsewhere, always beyond the frame. And yet, pictures are powerful vehicles of memory. I pointed out earlier that the last story in The Dark Room raised the disturbing question of whether by not refusing memory, as Micha does, one can truly purge oneself of its wounds. The book's ending suggests that working through may not amount to purging oneself of the wounds of memory. Memory restores and hurts, just as a picture shows and hides, tells and fails to tell. One of the messages that Seiffert's work conveys is that working through may rather mean to find ways to live with the gaps and the wounds of the past. It is only by coming to terms with what came before that one is able to look ahead, aware of, but not trapped by that past - even if it still hurts, even if there is no end to it. ${ }^{8}$

\section{Notes}

1. Rachel Seiffert is half-German. She was born in England, in 1971, to an Australian father and a German mother. Though brought up in England, she was raised bilingually and visited Germany regularly. She has kept a close relationship with her German relatives, and even lived in Berlin for some time.

2. See, for instance, Peter Sichrovsky's groundbreaking Born Guilty. Children of Nazi Families (1988) and other later studies such as Bar-On 1989, Rosenthal 1998, and Sereny 2001.

3. The other works dealt with by Zeitlin are Tales of the Master Race (1991), by the American Marcie Hershman, and The Inventory (2001), by the German-Jewish Gila Lustiger (translated from the German Die Bestandsaufnahme, 1995).

4. As one reviewer puts it, in The Dark Room pictures are "taken, framed, buried, stolen, burnt, copied and sought for" (Spencer, 2002). They figure prominently in the narrative, but there are no actual photos included.

5. The Dark Room 26. Hereafter TDR will be used in parenthetical references.

6. Nicolas Abraham and Maria Torok's concept of the phantom enables them to postulate how influences outside an individual's consciously lived experience can determine psychic development by linking some states of mental disarray to the concealment of a secret, rather than to that individual's unconscious understood as a repository of repressed wishes. The secrets, the buried speech of the parents, will be a gap in the child, an unknown phantom that returns from the unconscious to haunt its host. For more on this, see Abraham and Torok 1994.

7. Roland Barthes chooses the word "Spectrum" to refer to the person or thing photographed, the target of the picture. He calls it "the Spectrum of the Photograph because this word retains, through its root, a relation to 'spectacle' and adds to it that rather terrible thing which is there in every photograph: the return of the dead" (2000:9).

8. The research carried out for the writing of this article is part of a project financed by the Spanish Ministry of Science and Innovation (MICINN) and the European Regional Development Fund (ERDF) (code HUM2007-61035). The author is also thankful for the support of the Government of Aragón and the European Social Fund (ESF) (code H05). 


\section{References}

Abraham, Nicolas (1987): "Notes on the Phantom: A Complement to Freud's Metapsychology." Critical Inquiry 13(2): 287-292.

Abraham, Nicolas and Maria Torok (1994): The Shell and the Kernel: Renewals of Psychoanalysis, Vol. I. Ed., trans., and intro. Nicholas T. Rand. Chicago: University of Chicago Press.

"Author Interview: A Conversation with Rachel Seiffert, Author of The Dark Room." Random House.Inc. Retrieved on 14 December 2009 at:

$\mathrm{http}: / / \mathrm{www}$. randomhouse.com/catalog/display.pperl?isbn=9780375726323\&view=auqa

Baer, Ulrich (2002): Spectral Evidence: The Photography of Trauma. Cambridge, Mass.: MIT Press.

Bar-On, Dan (1989): Legacy of Silence. Encounters with Children of the Third Reich. Cambridge, Mass.: Harvard University Press, 1989.

Barthes, Roland (2000): Camera Lucida. Trans. Richard Howard. London: Vintage.

Hirsch, Marianne (2001): "Surviving Images: Holocaust Photographs and the Work of Postmemory." The Yale Journal of Criticism 14(1): 5-37.

Hirsch, Marianne and Leo Spitzer (2006): "What's Wrong with this Picture? Archival Photographs in Contemporary Narratives." Journal of Modern Jewish Studies 5(2): 229252.

Osman, Coli (ed.)(1987): George Roger: Magnum Opus. Fifty Years in Photo Journalism. Berlin: Nishen.

Rau, Petra (2006): "Beyond Punctum and Studium. Trauma and Photography in Rachel Seiffert's The Dark Room." Journal of European Studies 36(3): 295-325.

Rosenthal, Gabriele (1998): "National Socialism and Antisemitism in Intergenerational Dialog." In Grabriele Rosenthal, ed., The Holocaust in Three Generations. Families of Victims and Perpetrators of the Nazi Regime. London: Cassell, 240-247.

Rosenthal, Gabriele (ed.)(1998): The Holocaust in Three Generations. Families of Victims and Perpetrators of the Nazi Regime. London: Cassell.

Sacks, David (2001): "Sins of the Fatherland." The New York Times on the Web. Books 13 May. Retrieved on 14 December 2009 at <http://www.nytimes.com/books/01/05/13/ reviews/010513.13sacks2t.html>

Seiffert, Rachel (2002): The Dark Room. London: Vintage.

Sereny, Gitta (2001): The German Trauma. Experiences and Reflections 1938-2001. Harmondsworth: Penguin.

Sichrovsky, Peter (1988): Born Guilty. Children of Nazi Families. Trans. Jean Steinberg. New York: Basic Books.

Sontag, Susan (1977): On Photography. New York: Penguin.

Spencer, Sally-Ann (2002): "Rachel Seiffert -The Dark Room.” SpikeMagazine.com. Retrieved on 5 December 2008 at <http://www.spikemagazine.com/1002seiffert.php>

Todorov, Tzvetan (1997): Facing the Extreme. Moral Life in the Concentration Camps. Trans. Arthur Denner and Abigail Pollak. New York: Owl Books.

Tollance, Pascale (2005): "Freezing Emotions: the Impersonality of 'Photographic Writing' in Rachel Seiffert's The Dark Room." In Christine Reyner and Jean-Michel Ganteau, eds., Impersonality and Emotion in Twentieth-Century British Literature. Montpellier: Publications Montpellier 3, 287-298. 
Wachtel, Eleanor (1996): "Eleanor Wachtel with Martin Amis: Interview." Malahat Review 114: 45-64.

Zeitlin, Froma I. (2006): "Imaginary Tales in the Land of the Perpetrators." Journal of Modern Jewish Studies 5(2): 213-228. 